\title{
The Style Of Language Used In Hospitality Industry
}

\author{
Made Budiarsa ${ }^{1}$ \\ Udayana University Bali ${ }^{1}$ \\ \{made_budiarsa@yahoo.com ${ }^{1}$ \}
}

\begin{abstract}
The use of language (function of language) according to Halliday (1985) is a language used as a means of communication in society. The word usage can simply be said to have the same meaning as the function of language. The purpose of this study was to determine the style of language used in the tourism industry. when talking about the use of language, it means the way someone uses their language or their languages if they know more than one language. The data source of this research was taken from speakers in the tourism area in South Bali, which belongs to the area of Badung Regency. Why these locations were chosen as the research locations because these areas were considered as bilingual communities, so they were very suitable and in accordance with the objectives of this study. The choice of locations in the tourism areas of South Bali due to the fact that these tourism destinations are the center of tourism in Badung and the speaking community mostly comes from various regions in Indonesia and abroad. Language is a communication tool used by humans, including speakers in the tourism industry in their interactions with guests, fellow employees, as well as superiors and subordinates to convey intentions, thoughts and feelings. The languages used by speakers in the tourism area of South Bali include Indonesian, Balinese, foreign languages such as English, French, Japanese and others. To achieve these communication objectives the speakers used communication strategies including, code switching, code mixing and also the use of jargon related to the tourism industry.
\end{abstract}

Keywords: language; function; strategy; jargon; code switch

\section{Introduction}

The use of language is closely tied to the socio-cultural values of a speech community where the language is used. Therefore, the most appropriate approach used to reveal the styles of language use in the tourism industry, especially by speakers in the tourist destination of South Bali, is a sociolinguistic and socio-pragmatic approach. Why were sociolinguistic and socio-pragmatic approaches chosen in this study? The choice of sociolinguistic and sociopragmatic approaches has at least two reasons, namely (1) because speech has a social function, both as a means of communication and as a way of identifying social groups and (2) because the use of language in social interactions is a speech act that is more appropriately called with pragmatic terms. Fishman (1967) says that sociolinguistics provides knowledge about how to use language in interactions between speakers in society and at the same time 
explains how to use language in certain social aspects. As is well known, sociolinguistics is a combination of sociology and linguistics. These two fields of science are very closely related. Sociolinguistics studies the use of various language variations and their functions in society. As for linguistics, it is a science that studies the intricacies of the language.

Theoretically, the sociopragmatic approach in this study uses the ethnographic communication analysis model proposed by Hymes (1972). The model was used because all data in this study included things related to who speaks (or writes), what language (or what language variety), to whom and when, and to what end (Fishman, 1972) 'who speaks or writing, what form of language variation is used, to whom and when, and for what purpose '.

Based on the explanation above, it is very interesting to study in depth about the use of language which is a phenomenon that appears in people who involved in the world of bilingual tourism, such as in the tourism area of South Bali, which has been very well known

since time immemorial. Speakers in tourism areas mostly experience social shifts as a result of the influence of the progress of tourism development so that the way they use language also shows distinctive styles. The influence of tourism as a result of the interaction between ethnic groups who have very different socio-cultural backgrounds is evident in the language behavior of the people. This happens not only to people who are directly involved in the tourism industry, but also to other communities. In general, people who become employees in the tourism industry are able to use more than one language in one speech event. In other words, they belong to a multilingual society.

Haugen in Romaine (1995: 1) says that if a speaker of a language can produce meaningful complete utterances in another language, which is used in a speech event, that person can be considered a bilingual. Bilingualism is a condition in which individuals or societies have the styles of the presence of the use of two languages simultaneously. The term bilingual is sometimes used more specifically to refer to the situation of a person or society who uses only two languages, while grammar is a term used to refer to the situation of a community or speakers who use more than two languages. In this study the difference in terms is not discussed in detail because the term bilingual already includes the concept of grammar. What needs to be understood with regard to bilingualism is the phenomenon of code switching which is the most important aspect of bilingualism. It has been understood that code switching is the use of more than one language by a speaker in a speech event, or in other words it can be said that code switching is the use of more than one linguistic variation in a speech event or interaction.

\section{Research Methods}

The qualitative exploratory method is used as a basic foundation and work approach as well as a main element in certain social science research (Miles and Huberman, 1992: 1). In this connection, qualitative methods have been used as the basis of reference in this study. Qualitative analysis is carried out specifically from the collected data through interviews, records and skills, and observations or observations. Descriptive qualitative methods are used in this study in order to describe and explain the true nature or styles of the data and to be able to see the factors behind the styles of the data that have been obtained.

The data analysis in this study was carried out inductively because the inductive process is more able to find multiple realities as contained in the data. In addition, inductive analysis can make the relationship between the researcher and the respondent explicit, recognizable and accountable, and can fully describe the setting. The data analysis process was carried out 
starting from checking the identity of the informants, answering the questions / questionnaires that were asked, checking all recorded data from the results of interviews and observations, which were relevant to the purpose of this study. The recordings are then transcribed and classified according to their type according to the objectives to be achieved. Relevant and selected data are presented and explained one by one based on the sociolinguistic and sociopragmatic theories which have been established as the theoretical basis.

The data of this study include various kinds of speech in the form of spoken conversations using Indonesian, Balinese, and English as long as they contain variations in the use of communication strategies, and the use of special words related to jargon. In this study, a purposive sampling technique was used which was adjusted to the problem and purpose of this study, namely to determine the styles of language use by speakers in the tourist destinations of South Bali. By using this sampling technique, researchers do not need to use all available data, but only a few are taken which are considered to be representative of the entire population.

\section{Theoretical Framework}

As stated above, sociolinguistics is an interdisciplinary science, namely a combination of sociology and linguistics. To understand what is meant by sociolinguistics, it is necessary to understand what is meant by sociology and linguistics. Sociology is the study of humans in society, the institutions and social processes that exist in society. Sociology tries to find out how society occurs, takes place, and remains (Chaer and Agustina, 1995: 2). On the other hand, linguistics is a field of study that studies language as an object of study which includes the use of language by speakers in people's lives.

Hudson (1980) states that sociolinguistics is a science that studies language in relation to society. Part of sociolinguistic study is an empirical study and part of it is theoretical, that is, part of it is a problem of data collection, and part of it is part of thinking (Hudson, 1980: 1). The notion of sociolinguistics as an interdisciplinary science is a combination of sociology and linguistics. In social linguistic terms, the word socio which has the meaning of society is the main aspect in relation to sociological research and is a general feature of the field of science. On the other hand, linguistics has social styles because language has social styles, that is, language and its structure can only develop in a particular society. Sociolinguistics also concerns individuals because elements are often seen to involve individuals as a result of the individual's function as social beings.

The relationship of language with the speaking community can be seen by the existence of a relationship between certain language forms, which are called variations, varieties, or dialects with their use with certain functions in society. As stated by Chaer \& Agustina (1995: 51) that in the world of education, standard types are used, in daily activities at home, nonstandard varieties are usually used, in business activities, various types of business are used, and in activities to create works of art, various types of literature are used. The use of language or the choice of code is also determined by the social level of the community. The social level in question can be seen from (1) aristocratic status and (2) social position which can be seen from the level of education and the state of the economy one has. Based on these social levels in society, there are various variations of the language used according to the social level. This can be seen in the life of people in tourist areas in Bali. The language or language variations used by those working in the world of tourism are not the same as the variations used by those who are not involved in the world of tourism. They tend to use language variations mixed with 
other language variations. To what extent the truth of this statement will be examined more deeply in this study.

Halliday and Hasan (1985) say that the register is a semantic concept. The register itself is defined as a configuration of meaning that can be realized in the configuration of a particular situation concerning the field (what is being discussed), means, and actors. Because the register is a configuration of meaning, the register includes expressions, lexicogramatical, and phonological features that follow or realize these meanings (Halliday, 1985: 39). Halliday distinguishes registers into two, namely a limited register "close register" and an open register "more open register". Limited register "close register" has a very limited meaning and is usually used in certain institutions, such as airlines, military, banking, hospitality, and others that only use certain languages or terms. Open register "more open register" which concerns the use of language in official documents and forms. Registers such as these are also used to convey greetings in the form of greeting cards concerning personal matters and regarding news headlines and food recipes. There are also other forms of registers concerning their use in the classroom such as in the teaching and learning process; The registers used will differ from each level or level to one another.

The term register is used widely in sociolinguistics to refer to the variation of language according to its usage, while dialect is defined as the variation of language according to the speaker (Halliday, McIntosh, 1964). Dialects can be divided into two, namely social dialects and geographic dialects. Registers are language variations related to certain professions, hobbies, recreation, and others. The register also concerns the differences in grammatical selection and pronunciation, in this case the most consistent attribute which concerns a set of terms called jargon or argot (Fromkin, 1988: 277). Jargon is also a social variation that is used in a limited way by certain social groups. The expressions used are often not understood by the general public outside the group. However, these expressions are not secret.

\section{Results and Discussion}

Due to the limited pages for writing this paper is allowed by the seminar organizing committee, therefore the discussion of the results will be very limited, but can represent all the problems that have been presented in the above background.

\subsection{Code Switching}

Code switching is a phenomenon in bilingual societies, as often represent the case in tourist destinations. Code switching is switching the use of language variations to other language variations if the situation demands. It seems normal for a language to have many options for conveying the same thing in society. For example, in English "car" and "automobile" these two words have the same reference. In syntactic selection as in the sentence "Who is he talking to?" with "To whom is he talking?". In each case it seems difficult to determine the place of these linguistic variations in the linguistic structure. The latest formal analysis provides two options, namely (1) the variants are said to have different systems, the choice of this term is called a dialect mixture or code switching and (2) the variants have free-variation. Look at the following data:

"Appetizer adalah hidangan pembuka yang kadang-kadang disebut juga dengan istilah

"Hors D'oeuvre atau starter". Makanan pembuka yang dingin: yang berupa cocktail, melon cocktail, shrimp cocktail, fruit cocktail, dan sebagainya. 
In the above speech, three languages are used in one speech event, namely Inonesian, English, and French which are used to explain the types of appetizers. The speaker begins his speech using English, then he turns to Indonesian to explain the meaning of the word appetizer "opening food", which means the same as Hors D'oeuvre (French). This type of appetizer is usually only sold in restaurants with international standards. When viewed from the situation at the time the speech event occurred, the situation was very formal because it was explained to the training participants about the meaning of the inserted jargons.

\subsection{Jargon}

The use of jargon is very common in communication between speakers in tourist destinations, especially those related to the work in international restaurants. Why are there the use of code switching in the form of jargon happen in this speech event? The code switching occurred because the topic of conversation was related to the restaurants' terms in English which were difficult to be translated into Indonesian. It seems that in this situation it is more appropriate to use the jargon commonly used in international restaurants. This is also caused by the situation of the argument which requires code switching in the form of jargon. Based on the language used, namely Indonesian mixed with English and French jargons, it is clear that the participants in the speech are Indonesian because only occasionally the insertion of a foreign language occurs. On the other hand, the terms used in the form of English and French are jargons which are commonly used in the international restaurants.

As can be seen in the following data, a waiter in this conversation switches codes when he asks a friend for help in a restaurant while carrying out an assignment.

Head Waiter : Tamunya sudah selesai tolong clear up dan langsung di set up table 24.

Waite : Nggih Pak, masih ngambil cutlery di belakang tidak ada di side stand.

Head Waiter : Jangan lupa ganti table cloth nya.

Waiter : Nggih Pak.

In the above conversation, an interaction between a head waiter and a waiter occurs in a restaurant. This is marked by the use of vocabulary that refers to things that are commonly used in an international restaurant. The jargon that shows that this speech event occurred in a restaurant is the words clear up, set up table 24, cutlery, side stand, and table cloth. The switch of language from Indonesian into English jargon are commonly used in restaurants with international standards. The switch in language use from Indonesian to English shows the phenomenon of code switching and mixing occurrence. The jargon used in the speech event by the waiters illustrates that table 24 has just been used as a dining area for guests. Interaction between speakers in the speech event mentioned above did not experience any significant difficulties because they have already understood the jargon that is usually used in their daily interactions in restaurants where they usually do their work.

\subsection{Language Variations}

The use of language variations, especially formal Indonesian and non-formal Indonesian which are inserted with English jargon related to terms commonly used in hospitality industry is very common. It can be seen in the following one example of data.

"Selamat sore rekan-rekan semua. Pertama-pertama staf yang training akan dibagi menjadi 3 groups dan kenapa saya tambahkan juga dengan daily worker supaya nantinya si-daily worker kalo sewaktu-waktu diperlukan tidak ada perbedaan persepsi terhadap standard opertsional dari F\&B”. 
In the above data the speaker is an $\mathrm{F} \& \mathrm{~B}$ manager is giving an explanation to his staff using Indonesian about the training plan that will be given to all $\mathrm{F} \& \mathrm{~B}$ service staff, who will attend a three week training program. In delivering this program, speakers use Indonesian as a medium for conveying messages. Indonesian was chosen because all speech participants are Indonesian and understand Indonesian well, as well as to facilitate communication, avoid misunderstanding and show solidarity, however, variations in the use of Indonesian are often inserted with English. This was done because speakers wanted to emphasize and explain again about the training titles written in English that had been given to all training participants, which would be discussed in more depth in the training program.

The transition from Indonesian to several English terms used by speaker who has the status as an Food and Beverage manager shows that there are terms that are more appropriate to be used to remain in the English form rather than to provide their equivalent in Indonesian, which may be considered incorrect, or in this occasion the speakers want to emphasize to all staff about the English terms that are commonly used in the FB service section.

\section{Conclusion}

From the very short discussion above, it can be concluded that the styles of language use in the tourism industry are characterized by the use of code switching and code mixing. Code switching from Indonesian to Balinese or into foreign languages, especially English. The use of jargon illustrates the form of language used by speakers, especially jargon in English related to terms commonly used in the tourism industry, which are difficult to be translated into Indonesian. There are many uses of jargon related to terms in food and beverage, housekeeping, and front office. Likewise, the use of language variations in formal and nonformal forms is often encountered in speech if the speakers have different social distances, for example if there is an interaction between superiors and subordinates, there will be use of language in formal and informal forms.

\section{References}

[1] Chaer, Abdul and Leonie Agustina. 1995. Sosiolinguistik. Jakarta: PT Rineka Cipta.

[2] Fishman, J. A. 1971. "The Relationship Between Macro and Micro Sociolinguistics in the Study of Who Speaks What Language to Whom and When". Dalam J. B. Pride dan J. Holmes (ed.). Sociolinguistics. Hermondsworth: Penguin Books Ltd.

[3] Fromkin, V., R. Rodman, P. Collincs, dan B. David. 1988. An Introduction to Language. Sydney: Holt, Rinehart and Winston.

[4] Halliday, M.A.K., dan R. Hasan. 1985. Language, Context, and Text: Aspect of Language in a Social-Semiotic Perspective. Victoria: Deakin University Press.

[5] Haugen, E. 1972. The Echology of Language. California: Standard University Press.

[6] Haugen, E. 1966. “Dialect, Language and Nation”. Dalam J. B. Pride, dan J. Holmes. (ed.). Sociolinguistics. Hermondsworth: Penguin Books Ltd.

[7] Hudson, R.A. 1980. Sociolinguistics. Cambridge: Cambridge University Press. 
[8] Hymes, D. H. 1971. "On Communicative Competence". Dalam J. B. Pride dan J. Holmes. (ed.). Sociolinguistics. Hermondsworth: Penguin Books Ltd.

[9] Leech, G. 1983. The Principle of Pragmatics. London: Longman Group Ltd.

[10]Levinson, S. C. 1983. Pragmatics. Cambridge: Cambridge University Press.

[11] Poedjosoedarmo, Soepomo. 1976. "Keadaan Bahasa-Bahasa Daerah". (Bahan Penataran Dialektologi Tahap I). Tugu Bogor: Pusat Pembinaan dan Pengembangan Bahasa, Depdikbud. 